\section{US backs new policy on plutonium}

Washington

The Reagan Administration rallied behind the International Atomic Energy Agency (IAEA) last week, claiming that a strong international safeguards system was essential for the development of nuclear commerce. It argued that weaknesses in the safeguards system should be remedied by greater support for IAEA programmes, not by changing their basic objectives.

The Administration's views were given in testimony to two subcommittees of the House of Representatives' Foreign Affairs Committee. One issue was the adequacy of the Administration's proposed contribution to IAEA in the 1983 budget. Although the increase over the 1982 contribution is larger than that for any other international organization, it will still not be enough to keep up with inflation - a source of concern to some State Department of ficials faced with rapidly growing demands for IAEA inspection procedures.

The hearing was also an opportunity for the State Department to rebut some recent criticisms of IAEA, in particular complaints about its admission last year (in connection with a reactor in Pakistan) that it cannot always assure member countries that nuclear materials are not diverted from peaceful to military purposes.

Such criticisms, State Department officials argued last week, are not only misdirected but also potentially harmful, tending to undermine the credibility of IAEA. Mr Richard T. Kennedy, UnderSecretary of State for Management and head of the delegation to IAEA, angrily rejected charges by Congressman Richard Ottinger that the agency had been involved in a "cover-up" by not making public its concern about the possibility of the diversion of nuclear material in countries such as Iraq and Pakistan.

Mr Kennedy was accompanied at the witness table by Ambassador Richard Kirk, deputy US representative to IAEA, and Dr Eugene Rostow, head of the Arms Control and Disarmament Agency. Each spoke strongly on the theme that the agency requires as much support as possible from the industrialized nations, and that the adequacy of safeguards should not be considered in isolation, but merely as one element in the control of nuclear proliferation.

Thus Mr Rostow told the subcommittees that halting the spread of nuclear explosives was "inconceivable" without IAEA safeguards, but added that they did not prevent diversion since, for example, they did not permit searches for clandestine materials or facilities. "In my view, it is just as wrong to overestimate the importance of safeguards in nuclear commerce as it is to denigrate the system for not accomplishing objectives for which it was not designed," Mr Rostow said.

The State Department's consensus on IAEA, however, was not shared by all members of the Nuclear Regulatory Commission (NRC). Under the terms of the Nuclear Non-Proliferation Act of 1978 , the commission is responsible for checking that safeguards are applied to any foreign nuclear installation to which nuclear materials are being exported from the United States.

$\mathrm{Mr}$ Peter Bradford, on his last day as one of the five members of NRC, was outspoken about the difficulties experienced by both NRC and congressional committees in obtaining data by which to assess the effectiveness of the safeguards. At one point, he accused the State Department of unnecessarily censoring NRC's reply to questions submitted by Congressman Richard Ottinger.

Mr Kennedy refuted the charge of censorship, pointing out that the information was being withheld at the request of the Central Intelligence Agency - which has since offered to brief $\mathrm{Mr}$ Ottinger on the subjects that he had inquired about. Both he and Dr Rostow, however, declined to say whether the State Department has evidence of the diversion of nuclear materials.

Both Mr Bradford and a second NRC commissioner, Mr Victor Gilinsky, expressed reservations about the adequacy of IAEA inspection procedures for warning about the diversion of weaponsgrade plutonium from reprocessing or enrichment facilities - concerns which led the Carter Administration to attempt to dissuade other countries from adopting such technologies.

Dr Rostow in reply criticized the previous Administration's approach, suggesting that attempts to impose unilateral controls could backfire by encouraging the spread of reprocessing while making less likely the agreements on a common policy with other nuclear suppliers. The Administration's policy is soon to be defined in a new executive order which Mr Reagan is to sign; Dr Rostow said it was important to acknowledge that civil reprocessing in the stable industrial democracies did not in themselves present a proliferation risk.

On the IAEA safeguards, Dr Rostow urged that member states should provide the international safeguards system with the resources needed. Mr Kirk, however, told the subcommittees that as the number of installations under IAEA safeguards had risen from 560 in 1977 to 850 in 1981 , even though the IAEA budget allowed much faster growth for safeguards than in other activities, its expansion of the safeguards system had caused "a resources pinch, growing pains in IAEA's administrative structure, and a lag in IAEA safeguards coverage".

David Dickson

\title{
Nuclear monitoring by telephone
}

\section{Washington}

A scheme for collecting nuclear safeguards information by means of telephone lines is to be discussed at a meeting planned for Vienna in June this year. The system, called the Remote Continual Verification programme (or "RECOVER"), which was given a systematic trial in the autumn of 1980, has grown out of the technical proposals for the remote verification of arms control agreements in the draft of the Comprehensive Test Ban Agreement, uncompleted since the end of 1980 .

In evidence to the House of Representatives last week, Dr Eugene Rostow said that on the basis of a cost-benefit study carried out at Brookhaven National Laboratory, the Administration was now hoping that the system could be put into service soon, and that it might even be valuable in the verification of treaties (yet to be negotiated) on chemical and biological weapons.

In the nuclear context, the new system is a means of making sure that automatic monitoring equipment does not break down between visits by inspectors from the
International Atomic Energy Agency (IAEA). This is done by the repeated but irregular interrogation of monitoring equipment by means of signals transmitted on the international trunk telephone system. So that the authorities responsible for safeguarded nuclear installations cannot corrupt the signals received and sent, signals are encoded by means of an unbreakable code of the type developed for use in what is now called public-key crytography.

The Brookhaven study has apparently shown that the new monitoring system is potentially most valuable in nuclear installations such as reactors which can be refuelled on load and in fast critical assemblies, to which frequent visits from inspectors are at present required. One critical assembly in Japan, containing a fixed quantity of $300 \mathrm{~kg}$ of plutonium and $200 \mathrm{~kg}$ of enriched uranium, has on present criteria to be inspected every week or two

The new monitoring system, by reducing the frequency of inspections, would save an estimated $\$ 200,000$ a year at that installation alone. The system is, however, 
unlikely to be used at separation plants (where inspectors are virtually permanently in residence) or in light-water reactors (where redundant monitoring equipment is probably cheaper).

In Japan, the system is also being advocated as a means of safeguarding the sea transport of fissile material, providing a means of making sure that cargoes are not illicitly diverted on the high seas. In such an application, communication would be by means of Earth satellites of the kinds being developed for marine navigation. The effective use of the system for the inspection of nuclear installations on land is thought to require the development of a network of IAEA field stations (of which there are at present only two, in Toronto and Tokyo) and the existence of an efficient trunk telephone system (found wanting in Bulgaria during the 1980 trial of the system).

The application of the system to the monitoring of agreements on chemical and biological weapons presupposes the design and installation of effective automatic monitoring equipment at plants covered by an agreement.

\section{Soviet nuclear power}

\section{Signs of caution}

The Soviet nuclear energy programme is running into difficulties. In spite of the high priority given to power station construction, last year's targets were not met. And although no specific reference has been made to the need for greater standards of safety, Pavel Falaleev, first deputy Minister of Energy and Electrification, has said that the safety requirements of power stations were being tightened despite the radiation around them being "considerably below the permissible limit and practically no different from natural levels "'. In a Soviet context such a remark is sufficient to indicate considerable high-level rethinking.

The discussion of the nuclear programme began about six weeks ago, with a meeting of the Central Committee of the Communist Party to review shortcomings, where the emphasis was on the logistics of construction although inadequacies in the design sector were noted.

Three weeks later, the theme was taken up in a leading article in Pravda. This at first followed the line of the central committee meeting, noting that production-line nuclear power units had already been developed, and that supply problems could be dealt with by economic sanctions to penalize those who held up the plan. Pravda then went on, however, to suggest serious deficiencies in the design sector.

Here, it was claimed, the Ministry of Energy and Electrification had failed to exercise its supervisory duties. Changes in materials and specifications had been made without either proper justification or the

\section{Sticky problem over Iraq fuel supplies}

Two French nuclear physicists, backed by three prestigious members of the Academie des Sciences, have warned President Mitterrand in a report that there would be no easy way to stop Iraq making bomb-grade plutonium if France rebuilt the Osirak reactor destroyed in a bombing raid by Israel nearly a year ago.

This is the second report condemning the reactor sale to be prepared by the two physicists and to be sent unsolicited - to the president who is said to be sympathetic to the arguments but to be short of apolitical technical advice.

What stung the physicists to produce a second report were widely-reported claims that "caramel" - a low (7 per cent) enriched uranium oxide fuel was the answer to the problem. If caramel were sold to Iraq to fuel the reactor, in place of the 95 per cent enriched uranium for which it was originally designed, the claims went, Iraq would have no quick route to the atomic bomb.

However, this misses the point, the new report stresses. The caramel fuel would still produce the same neutron intensity in the large pool around the reactor, where test materials are placed to investigate their reaction to neutron bombardment. If these test materials were replaced by depleted - or natural - uranium (of which Iraq is believed to have supplies) plutonium would be produced in the uranium, and could be extracted chemically.

apparatus for selecting the "most progressive"' solution to engineering problems. In particular, a proposal put forward by the Atomenergostroiproekt design trust, for a change in the structure of the "protective shells" of power stations, was turned down without being studied by the necessary multi-disciplinary panel of experts. The scientific council of the ministry, Pravda said, must bear greater responsibility for such decisions.

This reference to protective shells is significant. If, as seems likely, this refers to the concrete containment vessel common in Western power stations, it reflects a change in Soviet policy. Until recently, such vessels were dismissed by Soviet designers as unnecessary, and a capitalist ploy to raise construction costs. Demands from the Finns and Hungarians led them to introduce containment vessels into reactors designed for export. The remark in Pravda suggests that they may now have been introduced into reactors for home use whereas previously it was thought sufficient to surround reactors on the outskirts of major cities with a kilometre or two of parkland or playing fields.

Vera Rich
The only advantage of caramel is that it cannot be used directly to make bombs, whereas 95 per cent enriched uranium is more easily converted. But, the reports point out, four years ago Giscard d'Estaing set limits on deliveries of enriched fuel to Iraq. Fuel would be sent in single reactor-loads of $13 \mathrm{~kg}$, each of which would be loaded into the reactor under supervision and promptly irradiated making diversion technically very awkward. From that time, the diversion of the fuel itself ceased to be a problem - so the use of caramel solved nothing.

The production of plutonium by neutron bombardment, however, could amount to 3.3-8 kilogramme per year (to quote the assessments fo both the Commissariat à l'Energie Atomique and the International Atomic Energy Agency). The amount of plutonium required for a bomb is generally taken to be $6 \mathrm{~kg}$, although under certain circumstances 1-2 kg could be enough. Thus, say the two reports, Iraq could have the capability (in plutonium, at least) of producing a bomb within six months of beginning irradiation, whatever fuel the reactor was loaded with. IAEA inspection, however, might interfere considerably with this rate of production.

France has said it will help rebuild Osirak, provided Iraq guarantees that the reactor will be used entirely for peaceful purposes. The new report may make this politically more difficult for the president.

Robert Walgate

\section{Intelligence testing}

\section{Soviet inequality}

The Russians have finally "come out" on the subject of intelligence and other objective tests of performance and personality. The January/February issue of Voprosy Psikhologii (Problems of Psychology) contains three papers endorsing such tests in principle.

The papers are printed prominently at the front of the journal, preceded only by a major statement on future psychology services policy, based on the decisions of the November plenum of the Soviet Union's ruling communist party. The journal quotes President Brezhnev himself in support of a call to concentrate on "scientifically-based solutions to the problems of the nation's education in the service of the scientific and technological revolution",.

This is a startling but unequivocal volteface by the Soviet authorities, who have until now (in public at least) regarded "testology" as an instrument of class warfare in the hands of the ruling capitalist élite. Testing was even made illegal in 